\title{
好中球スーパーオキサイド産生能 に関する基礎的並びに臨床的研究
}

\author{
第 1 編 \\ 好中球スーパーオキサイド産生能 \\ の測定に関する基礎的検討 \\ 岡山大学医学部第 2 内科（主任：木村郁郎教授） \\ 厚井文 -
}

（昭和56年 7 月 24 日受稿）

Key words: . superoxide production neutrophilic granulocyte aging neutrophil

绪

生体内における好中球機能は主に異物亚びに細 菌の会食と細胞内殺菌に代表される生体の防禦 であり，その機序，過程における生物学的並び に生化学的反応が諸家により報告されているリー4 ? 令食時の生化学的反応としては，好中球の著明 な酸素消費 ${ }^{5127}$,五炭糖りン酸化回路の活性化 ${ }^{8) 9}$, そして又同時に惹起される活性酸素の産生 ${ }^{10) ~ 13) ~}$ が注目されているが、このことはこれまで好中 球の細胞内殺菌作用が頜食という生物学的そし て形態学的反応においてのみ論じられる傾向に あったのに对し，その機序の複雑性を示すをの であろう。すでに慢性肉芽腫症 (CGD) の好中 球は正常な領食能を示すものの細胞内殺菌を全 〈示さず，領食に随伴する酸素消費 ${ }^{14115}$ ，五炭 糖リン酸化回路の活性化 ${ }^{14) 18)}$, 活性酸素の産生 1213)16)17)も認められない事が特徴とされている が,これら好中球機能に関した一連の研究は生 体防禦における好中球機能が“細菌領食一酸素 消費一活性酸素の産生”という密接な関連にお いて論じられる必要性を示すものであり、これ まで論じられた生物学的・形悲学的反応様式か らのより詳細な解明とその臨床医学への導入が 必要なことを示すものと思われる。
領食に伴って産生される活性酸素にはSuperoxide anion $\left(\mathrm{O}_{2}^{-}\right)^{1012) 20}$, Hydrogen peroxide $\left(\mathrm{H}_{2} \mathrm{O}_{2}\right)^{11) 21)}$, Hydroxyl radical $(\mathrm{OH} \cdot)^{13)}$, Singlet oxygen $\left({ }^{1} \mathrm{O}_{2}\right)^{22) 23)}$ が知られており,とくに $\mathrm{O}_{2}^{-}$は1973年 Babior ら ${ }^{10}$ が好中球にラテッスス 粒子を貪食させることによク，細胞外液中へ放 出されることをチトクロームC還元法を用いて 最初に証明した活性酸素である，又最近 $\mathrm{O}_{2}$-測 定法について，異物の領食という方法によらず 好中球代謝変化を誘導しうる物質 (membrane mimicker)を用うる方法が Nakagawara ら 1624 によって報告され，その各分野での応用が期待 されている。すなわちこれまで $\mathrm{O}_{2}{ }^{-}$産生能の測 定は CGD患者の発見, さらに CGD キャリャー のスクリーニング25りに主に応用されその有用性 が評価されてきたが, CGD 以外に細胞内殺菌能 異常が推定される各種疾患，そして又各種病態 への臨床応用が期待されるのではないかと考え られる。

さて急性白血病における治療理念は total leukemic cell kill 基盤としており，各種抗白血 病剤の導入そして又 supportive therapyの進歩 により加速度的にその寛解導入率の上昇と生存 期間の延長が認められるようになったことは言 うまでもない26). しかし今尚白血病細胞に対し 
選択的に殺細胞作用を及ぼす薬剤が無い現在, 化学療法時の正常造血能の抑制とそれに随伴す る感染症の管理が極めて重要な問題として提起 され27)，その臨床管理は“急性白血病では何故 易感染性なのか”という問題提起の中でより科 学的に展開される必要性があろう。急性白血病 における感染症合併の最も大きな因子が白血病 細胞增多による正常顆粒球采の圧排，そして又 化学療法による正常好中球の減少281にあること は言うまでもないが,ささらに本病態における好 中球機能そして又抗白血病剤の好中球機能に及 ほす影響など，内因的・外因的要因がより明確 にされる必要があるものと思われる。

今回著者は以上の観点に立ち, 急性白血病に おける好中球機能さらに又抗白血病剤の好中球 機能に及ほす影響を, $\mathrm{O}_{2}^{-}$産生能の面から検討 することによって急性白血病の易感染性にアプ ローチしたが，まず本編では $\mathrm{O}_{2}$-産生能測定に 関する基礎的検討, すなわち至適実験条件の設 定と正常七卜好中球 $\mathrm{O}_{2}-$ 産生能, 特にそれに対 する宿主因子としての性別, 加令の影響を明確 にせんとした.

\section{研究对象及び方法}

\section{1) 対象}

20８9才（平均47才，男女比43：24）の健康 成人67名を対象とした。

2 ）白血球分離方法

肘静脈よりへパリン加静脈血 $5 \mathrm{~m} \ell$ を得， $6 \%$ デキストラン生食水を $5: 1$ の割合で加え, 室 温に 30〜 45分間静置後得た buffy coat をプラス チック遠沈管にとク， $4{ }^{\circ} \mathrm{C} て ゙ 150 \mathrm{G} 10$ 分間遠沈す

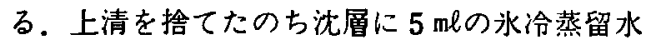
を加之充分に pipeting しつつ赤血球の低張処理 を行なった。さらに 60 秒後, $1.8 \%$ 水冷食塩水 $5 \mathrm{~m} \ell$ を加之等張に戻し， $4{ }^{\circ} \mathrm{C} て ゙ 150 \mathrm{G} 10$ 分間遠 沈，上清を捨てたのち沈層に $5 \mathrm{~m} \ell$ modified Krebs Ringer Phosphate buffer (KRP) ( $\mathrm{pH} \mathrm{7.4)}$ を加之, 細胞浮遊液にしたのち 3 分間水冷中に 静置した。つぎに沈殿した血小板凝集塊を混じ ないように白血球層を採取し，再び150 G 10 分 間遠沈後上清を捨て, KRP 0.5 $1 \mathrm{~m} \ell$ を加えて 白血球浮遊液を作成し，その細胞数を計算後測
定まで水中に保存した，尚各実験施行ごとに白 血球の viability trypan blue dye exclusion method で検討したがすべて $98 \%$ 以上であった． 3) $\mathrm{O}_{2}{ }^{-}$測定方法

$65 \mu \mathrm{M}$ 酸化型 cytochrome C, $0.05 \mathrm{mM}$ glucose を含む KRP に白血球を $0.25 \times 10^{6} \sqsupset / m \ell の$ 濃度に加之, $37^{\circ} \mathrm{C} 5$ 分間 incubate, 次いでConcanavalin A (Con A) とCytochalasin D (Cyt. D）をそれぞれ $100 \mu \mathrm{g} / \mathrm{m} \ell, 20 \mu \mathrm{g} / \mathrm{d} \ell$ の最終濃度 となるように同時添加し，最終反沈液量を 2.0

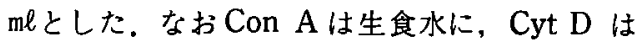
dimethyl sulfoxide (DMSO)に溶解した. 産生さ れる $\mathrm{O}_{2}$ による cytochrome $\mathrm{C}$ の還元を波長 550 nmにおける吸光度変化として, double beam spectrophotometer UV-210A (島津)を用いて 測定し, 紙送りスピード $15 \mathrm{~mm} / \mathrm{min} に て$ 経時的に 記録した。な好中球 $\mathrm{O}_{2}$ 一産生能は，白血球浮 遊液より叙沫標本を作成し May-Giemsa染色後, 好中球（桿状球十多核球）の割合を求め，好中 球 $10^{6}$ コあたりの産生能として現した。

4 ) 反応温度の好中球 $\mathrm{O}_{2}-$ 産生能に及ほす影響 $\mathrm{KRP}$ 液を $20^{\circ} \mathrm{C}, 25^{\circ} \mathrm{C}, 30^{\circ} \mathrm{C}, 37^{\circ} \mathrm{C}, 40^{\circ} \mathrm{C}, 45$ ${ }^{\circ} \mathrm{C} の$ 各温度に一定させたうえ，上述の方法を用 いて作成した白血球浮遊液を加之， 3 分間 incubate したのち， $\mathrm{O}_{2}{ }^{-}$産生能を各温度群で比較 検討した。

5 ）反応液 $\mathrm{pH}$ の好中球 $\mathrm{O}_{2}^{-}$産生能に及はす影 響

KRP 液を $0.1 \mathrm{H} \mathrm{HCl}, 0.1 \mathrm{~N} \mathrm{NaOH} に て \mathrm{pH}$ $6.0,6.5,7.0,7.4,8.0$ とし，上述の方法に従い各 $\mathrm{pH}$ における産生能を比較検討した.

\section{実 験 結 果}

1 ) 正常好中球の $\mathrm{O}_{2}^{-}$産生曲線

正常七卜好中球の $\mathrm{O}_{2}$-産生曲線は図 1 に示す ごとくで，まずゆるやかなチトクロームCの還 元に引続いて $2-3$ 分後には還元が恒常状悲と なり直線として記録された。直線化して 5 分後 $に$ Superoxide Dismutase (SOD) $20 \mu \mathrm{g} / \mathrm{m} \ell$ を反 応液中に添加すると直線は完全に平坦化し，抑 制がみられた。

2 ) 白血球保存温度の $\mathrm{O}_{2}$-産生能に及ぼす影響 分離後の白血球を氷冷中に保存し，経時的に 
図 1 好中球 $\mathrm{O}_{2}$ - 産生曲線

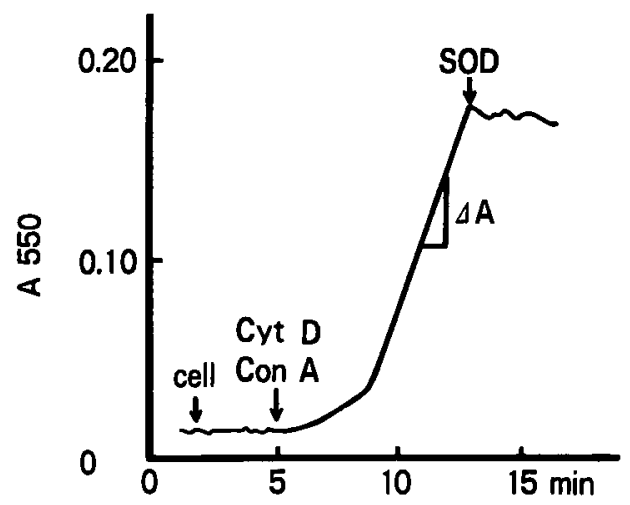

Superoxide production $=\frac{\Delta \mathrm{A}}{0.0105} \mathrm{nmol} / \mathrm{min}$

Con A: Concanavalin A

Cyt D:Cytochalasin D

S O D : Superoxide dismutase

図 2 保存温度の好中球 $\mathrm{O}_{2}-$ 産生能に及ぼす影響

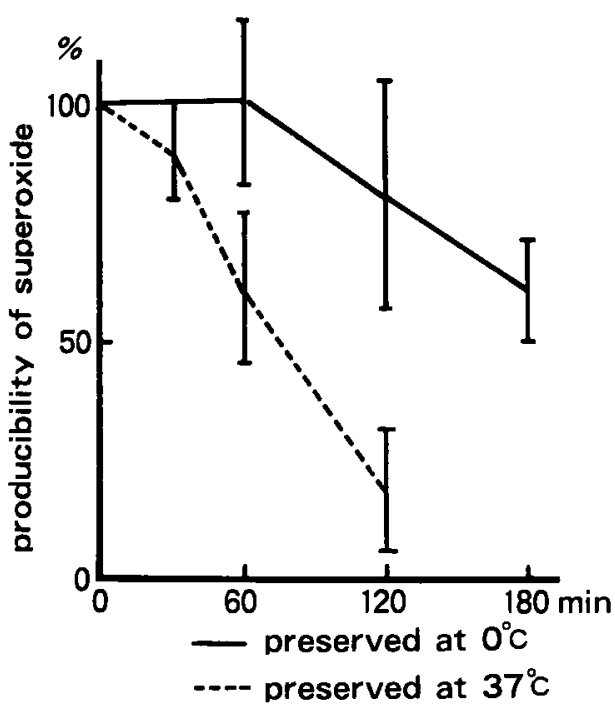

$\mathrm{O}_{2}$ 一産生能を検討した。その結果は図 2 に示す ことくで，白血球分離直後の $\mathrm{O}_{2}{ }^{-}$産生能を 100 \%とした場合，60分 $102.4 \pm 18.5 \% ， 120$ 分 81.4 $\pm 24.0 \%, 180$ 分60.1土12.1\%と60分まではほぼ 一定であった。一方分離後白血球を $37^{\circ} \mathrm{C} \mathrm{KRP}$ にて保存した場合，30分90.0土10.5\%,60分61.2 $\pm 15.4 \%, 120$ 分 $18.2 \pm 13.5 \%$ と $\mathrm{O}_{2}$ 一産生能は時 間依存性を示し著明に低下した。

3 ）白血球細胞濃度と好中球 $\mathrm{O}_{2}^{-}$座生能との関係
図 3 反応液細胞濃度と好中球 $\mathrm{O}_{2}-$ 産生能の関係

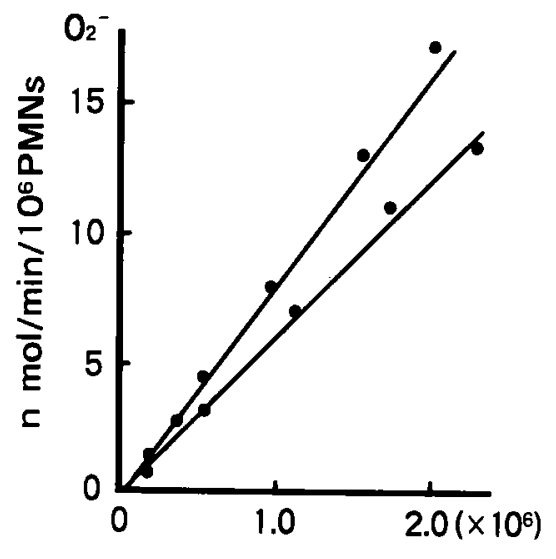

Number of $\mathrm{W} \mathrm{B} \mathrm{C/ml}$

図 4 反応液温度と好中球 $\mathrm{O}_{2}-$ 産生能の関係

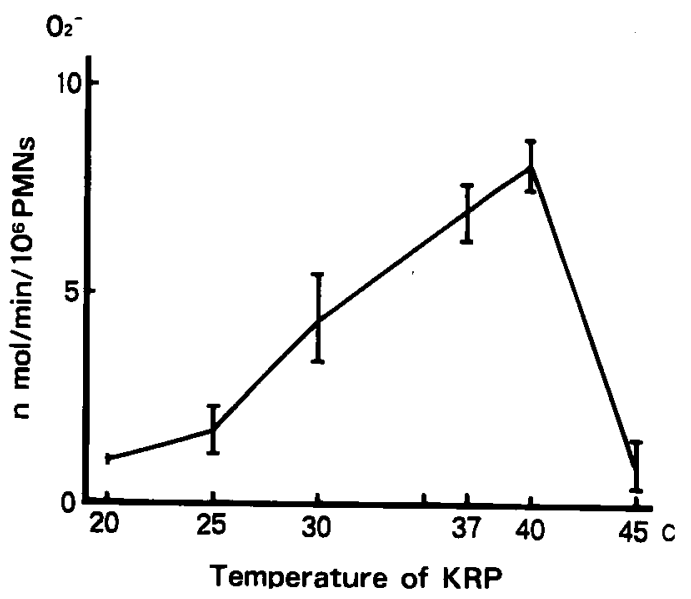

反応液中の細胞濃度を $0.1 \sim 1.5 \times 10^{6} / \mathrm{m} \ell の$ 範 囲で変化させ, 各濃度について $\mathrm{O}_{2}^{-}$産生能を検 討した。その結果は図 3 に示すことくで,この 範囲では細胞数と $\mathrm{O}_{2}-$ 産生能は正比例の関係を 示したが，細胞濃度が高くなるに従い $\mathrm{O}_{2}-$ 産生 能が一定状態に達するまでの時間(lag time)が 短縮する傾向が認められた，又細胞濃度が高い と incubation 時の基線の動摇が大きくなるとと もに, 直線の勾配が急峻化して $\mathrm{O}_{2}^{-}$産生能の算 出が不正確になる傾向が認められた。

4) 反応液温度の好中球 $\mathrm{O}_{2}$-産生能に及ぼす影響 正常人 3 名の白血球を用い検討した結果を図 4 に示した，各温度における好中球 $\mathrm{O}_{2}-$ 産生能は 
$20^{\circ} \mathrm{C}$ で $1.08 \pm 0.09,25^{\circ} \mathrm{C} 1.70 \pm 0.66,30^{\circ} \mathrm{C} 4.46$ $\pm 1.05,37^{\circ} \mathrm{C} 6.99 \pm 0.67,40^{\circ} \mathrm{C} 8.02 \pm 0.52,45$ ${ }^{\circ} \mathrm{C} 0.83 \pm 0.65 \mathrm{nmol} / \mathrm{min} / 10^{6} \mathrm{PMNs}$ であり, 40 ○において最も強い産生能が認められた。

5 ）反応液 $\mathrm{pH}$ の好中球 $\mathrm{O}_{2}-$ 産生能に及ぼす影響

実験 4 において検討した正常人 3 名の白血球 を用いた。その結果は図 5 に示すごとくで $\mathrm{pH}$

図 5 反応液 $\mathrm{pH}$ と好中球 $\mathrm{O}_{2}-$ 産生能の関係

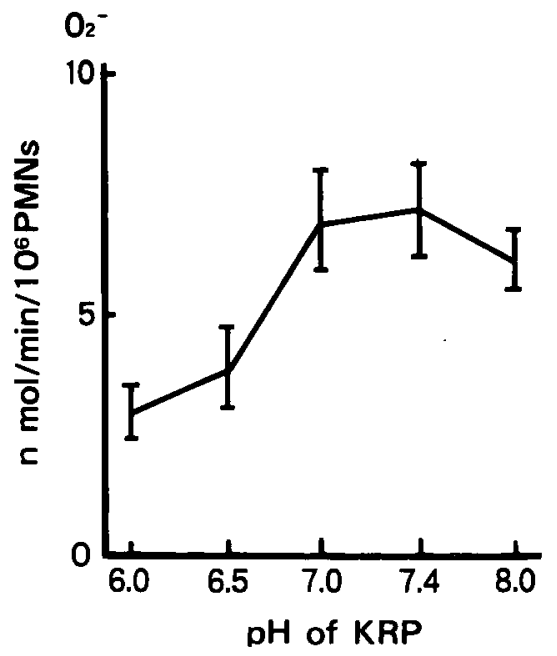

$6.52 .92 \pm 0.53$, pH $6.53 .86 \pm 0.88$, pH 7.0 $6.83 \pm 1,06, \mathrm{pH} 7.47 .22 \pm 0.85, \mathrm{pH} 8.06 .05$ $\pm 0.57 \mathrm{nmol} / \mathrm{min} / 10^{6} \mathrm{PMNs}$ であり $\mathrm{pH} 7.4$ に おいて最も強い産生能が認められた。

6 ) 好中球 $\mathrm{O}_{2}$-産生能測定值とその変動係数の 検討

正常人 3 名について好中球 $\mathrm{O}_{2}-$ 産生能をその 測定日時を変えて $5 \sim 15$ 回測定し，その測定值 の変動係数を検討した．表 1 に示すごとく変動

表 1 正常七ト 3 名における好中球 $\mathrm{O}_{2}-$ 産生能と その変動係数 $(\mathrm{CV})$

\begin{tabular}{cccc}
\hline Case & $\begin{array}{l}\text { No. of } \\
\text { experiment }\end{array}$ & Mean \pm SD & CV \\
\hline F.K & 15 & $7.18 \pm 0.84$ & $11.7 \%$ \\
KK & 6 & $5.81 \pm 0.64$ & $11.1 \%$ \\
KS & 5 & $728 \pm 0.73$ & $10.0 \%$ \\
\hline
\end{tabular}

係数はそれぞれ11.7，11.1 10.0,であった。 7 ) 正常七卜好中球 $\mathrm{O}_{2}-$ 産生能の検討
成績2）－6）より， $\mathrm{O}_{2}-$ 産生能の測定に際しての 至適条件は白血球保存温度 $\left(0^{\circ} \mathrm{C}\right)$, 白血球細胞 濃度 $\left(0.2 \sim 0.5 \times 10^{6} / \mathrm{m} \ell\right)$, 反応温度 $\left(37^{\circ} \mathrm{C}\right)$, 反 応液 $\mathrm{pH}(7.4)$ であり，これらの実験条件下で 正常七卜好中球 $\mathrm{O}_{2}$-産生能に及ぼす性別, 加令 の影響に对し検討を加えた。

(1)性別にみた好中球 $\mathrm{O}_{2}-$ 産生能

正常七ト $20 \sim 69$ 才の 45 名（男32名，女13名） の好中球 $\mathrm{O}_{2}$-産生能を男女間で比較すると, 男 性6.45 \pm 1.38 ，女性 $6.43 \pm 1.25 \mathrm{nmol} / \mathrm{min} / 10^{6}$ PMNs であり両群間に有意差は認められなかっ た(図6).

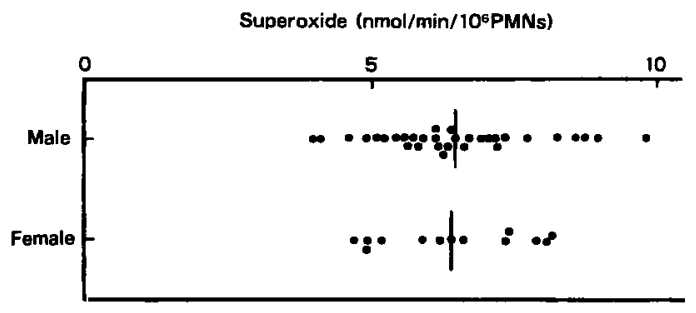

図 6 性別と好中球 $\mathrm{O}_{2}$ - 産生能

Superoxide $\mathrm{nmol} / \mathrm{min} / 10^{6} \mathrm{PMNS}$ )

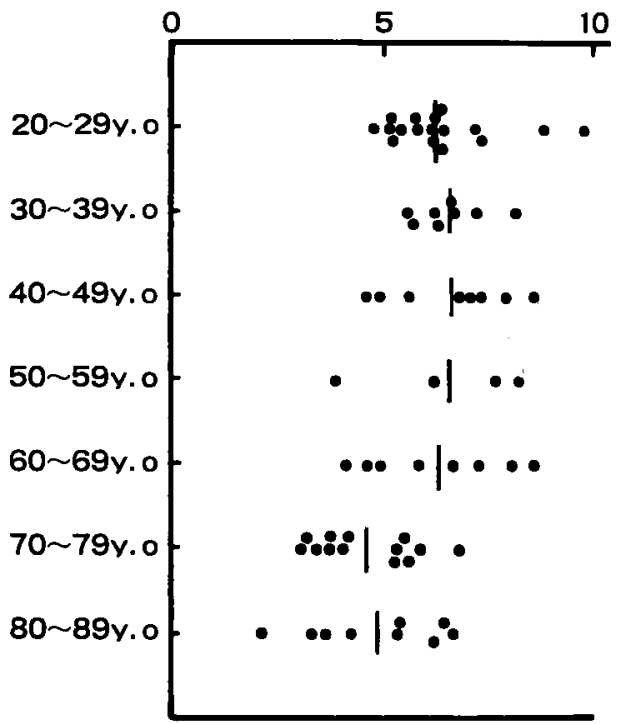

図 7 年令層別にみた好中球 $\mathrm{O}_{2}-$ 産生能

(2)好中球 $\mathrm{O}_{2}{ }^{-}$産生能に及ほす加令の影響 正常ヒト $20 \sim 89 \%$ の計 67 名における好中球 $\mathrm{O}_{\overline{2}}$ 産生能を一括し算出すると $5.88 \pm 1.56 \mathrm{nmol} / \mathrm{min} /$ 
106 PMNs であった。是らにこれを各年令層に おいて検討した結果を図 7 に示したが，20２9 才 $6.38 \pm 1.33(n=17), 30 \sim 39$ 才 $6.54 \pm 0.83(n$ $=8), 40 \sim 49$ 才 $6.60 \pm 1.41(\mathrm{n}=8), 50 \sim 59$ 才 $6.55 \pm 1.91(\mathrm{n}=4), 60 \sim 69 才 6.28 \pm 1.66$ $(n=8), 70 \sim 79$ 才 $4.59 \pm 1.20(n=13), 80 \sim 89$ 才 $4.90 \pm 1.65(\mathrm{n}=9) \mathrm{nmol} / \mathrm{min} / 10^{6} \mathrm{PMNs}$ であった.つぎに20〜 69才の非高令者層と70〜 89才の高令者層との 2 群についてその比較検討 を行なったが，その結果図 8 に示すごとく，非

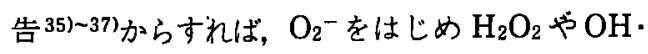
${ }^{1} \mathrm{O}_{2}$ が直接殺菌作用を示すと考えられる一方， $\mathrm{H}_{2} \mathrm{O}_{2}$ とミエロペルオキシダービさらにハロゲン 化イオンの反応系による強力な殺菌作用が存在 することも推定されており 29136)381，いずれの機 序によるにせよ，まず最初に $\mathrm{O}_{2}$-が産生される ことにより酸素依存性殺菌機構が作動する点か ら， $\mathrm{O}_{2}$-测定意義は極めて大きいと言えよう。

すでに述べたごとく Nakagawaraらの方法24) による好中球 $\mathrm{O}_{2}-$ 産生能湘定法は, これまで CGD

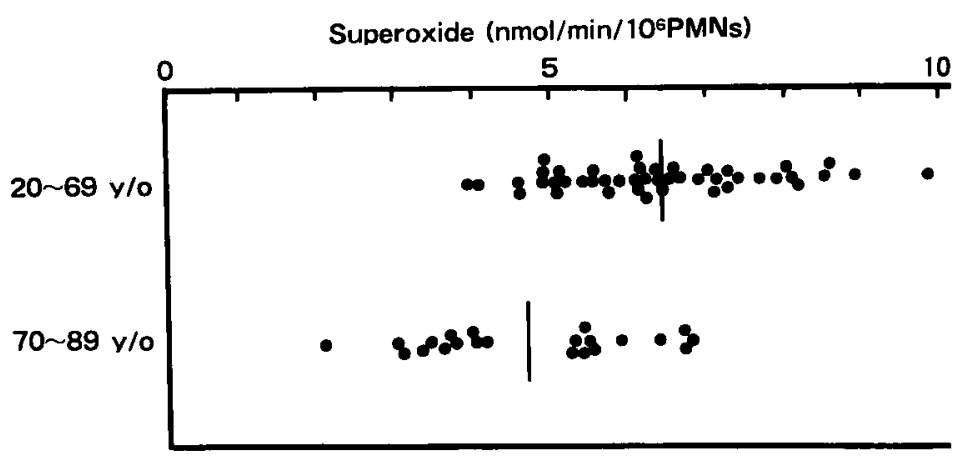

図 8 好中球 $\mathrm{O}_{2}-$ 産生能に及ぼす加令の影響 及じその保因者の検索に 用いられているが，それ 以外の分野での臨床応用 はなお少ない，本研究に おいて著者は急性白血病 の易感染性を好中球機能 の生化学的な検討からよ り明確にするため，本法 を用いて多角的に検討す ることを目的としたが, まず至適実験条件の確立 と正常ヒ卜好中球 $\mathrm{O}_{2}{ }^{-}$産 生能に及ぼす宿主要因の

高令者が6.45土1.33であったのに比し, 高令者で は4.72 $\pm 1.17 \mathrm{nmol} / \mathrm{min} / 10^{6} \mathrm{PMNs}$ と後者にお ける $\mathrm{O}_{2}$-産生能の有意な低下が認められた（P $<0.001$ ).

\section{考察}

これまで好中球における面食殺菌能の評価は 主に生物学的かつ形態学的に検討されてきたが, 近年その細胞内殺菌作用に酸素代謝 ${ }^{516) 7)}$ とくに 活性酸素10)-13)20)-22)29)が強〈関与していることが 諸家により報告されている、このことは好中球 殺菌能の評価に際し, 活性酸素産生能を中心と した生化学的アプローチの必要性を示すと同時 に，活性酸素産生能からみた好中球の病態解析 の必要性を示すものであろう。

さて好中球が胥食1012)あるいは又何らかの細 胞膜刺激 24),30)-33) を受けるとまず $\mathrm{O}_{2}{ }^{-}$が産生さ れるとともに $\mathrm{SOD} に よ り \mathrm{H}_{2} \mathrm{O}_{2}$ が産生される ${ }^{34)}$. In vitroの各種殺菌系に对して，それぞれの活 性酸素に対する scavengerの影響を検討した報
解析は，その臨床応用と臨床的意義づけに際し 極めて重要な点と考えられる。

さて実験条件とし，まず反応温度の $\mathrm{O}_{2}{ }^{-}$産生 能に及にすす影響をみると， $20^{\circ} \mathrm{C} 1.08 ， 25^{\circ} \mathrm{C} 1.70$ ， $30^{\circ} \mathrm{C} 4.46,37^{\circ} \mathrm{C} 6.99,40^{\circ} \mathrm{C} 8.02,45^{\circ} \mathrm{C} 0.83$ $\mathrm{nmol} / \mathrm{min} / 106 \mathrm{PMNs}$ であり，40ㄷお゙いて最

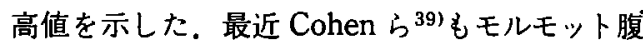
腔好中球を対象とし digitonin で刺激する方法で 同様の検討を行なっているが, その好中球 $\mathrm{O}_{2}{ }^{-}$ 産生能は著者の成績より低値を示しているもの の，温度の影響についてほほ同様の報告を行な っている。また $40^{\circ} \mathrm{Cにおける} \mathrm{O}_{2}$-産生は lag

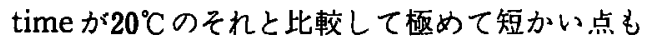
特徴であった。このことは生理的体温である37 ${ }^{\circ} \mathrm{C}$ を越え発熱した場合，好中球殺菌能が增強さ れた状態にあることを in vitroから示唆するも のと考之られ，感染状態における好中球機能を 検索する上で興味ある所見と解される。さらに 反応液 $\mathrm{pH}$ 変化の $\mathrm{O}_{2}{ }^{-}$産生能に及ばす影響を検 討したが，生理的 $\mathrm{pH}$ に近い $\mathrm{pH} 7.5$ で最も高值 
文

を示した．最近 Gabig ら ${ }^{40)}$ も著者の成績と同様 の結果を報告しているが，感染病单では好中球 細胞質顆粒の放出や自己融解により $\mathrm{pH}$ が低下 すると考之られており，生体内における好中球 機能とその直接の機能発揮の場との関連を考之 るとき興味深い所見と思われる。しかし生体内 感染巣における $\mathrm{pH}$ 低下はせいぜい $\mathrm{pH} 6.8$ 程度 までとされている点 ${ }^{41}$ 加らして，感染病巣へ浸 潤した好中球殺菌能への影響は一般に少ないと いえよう。

さて現在までのところ正常人における好中球 $\mathrm{O}_{2}-$ 産生能に関する報告は少なく，特に性別，年 令等の影響についての検討はほとれどみられず これら宿主要因の検討はすでに述へたごとくそ の病的状態での解析に対する本法の応用, そし て又その測定值の比較による意義づけを行なっ てゆく際，極めて重要である．著者は今回20才 以上89才までの67名の健康成人を対象とし，好 中球の $\mathrm{O}_{2}-$ 産生能を検討したわけであるが，ま ず同一例における測定值の変動係数は平均 10.9 であり，かなり再現性は良いと考えられた。次 に20オより10才間隔で各年令層別に検討した結 果, 70〜89才の高令者群では4.72 1.37 と20 69 才の $6.45 \pm 1.33 \mathrm{nmol} / \mathrm{min} / 10^{6} \mathrm{PMNs}$ に比し 有意に低值を示すことが認められた。すでに周 知のごとく高令者では一般に易感染性を示すと 同時に感染の難治化をきたしやすいことが特徴 とされているが42)，今回報告した加令による好 中球機能の低下は, 高令者感染㱏の特異性形成 に際し一つの要因となるものと思われる．現在 までに加令の好中球機能に及ほすす影響に関する 研究は極めて乏しく，Moronii ら ${ }^{43)}$ は60才以上 のヒト好中球について会食能と NBT 還元能を 検討した結果, いずれも40－59才のコントロー ル群に比し有意の低下を認めたとしている。ま た Silvermann ら ${ }^{44)}$ は好中球粘着能を検討した 結果，高令者群において有意の元進を認めたと 報告しているが，加令と好中球機能に関する研 究はこの 2 編にすぎない，本論文において著者 は，高令者好中球の細胞内殺菌能が有意に低下 している可能性を，その好中球 $\mathrm{O}_{2}-$ 産生能の検 討結果から推定したが, “何故 $\mathrm{O}_{2}-$ 産生能が加令 により低下するのが極めて興味ある問題と思

われる。これまで $\mathrm{O}_{2}{ }^{-}$産生およびその調節に対 L, 細胞膜 8 (33)451 -53), 解糖系 ${ }^{54) 55(56)}$ 及U゙五炭糖

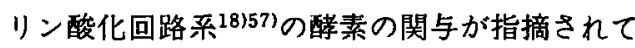
いるが，老化とともにおこる細胞膜脂質の過酸 化 ${ }^{58)} \rightarrow$ 膜構造や膜機能の変化 ${ }^{59) \sim 61)}$, 膜流動性 の低下 ${ }^{6263)} \rightarrow$ さらには膜結合醅素活性の低下 ${ }^{64)}$ は, 高令者における好中球 $\mathrm{O}_{2}{ }^{-}$産生能低下の妥 当性を膜変化の面から示㖫するものであろう。 また Holliday ら ${ }^{65)} は$ ，七ト胎児線維芽細胞を継 代培盖して老化細胞と若い世代の細胞中の酵素 を生化学的に比較検討し，老化細胞ではグルコ ース 6 リン酸脱水素酵素 (G6PD)のなか心著明 な熱不安定な成分が含まれていることを報告し ているが、このことは老化に伴う変異酵素の産 生を示唆したものであり，好中球の酸素代謝上 の key enzyme のUとつである G6PDをはじめ， 解糖系及び HMP 回路系の諸酵素活性の低下と 高令者における好中球 $\mathrm{O}_{2}-$ 産生能低下の間に, 醭素異常を中心とした有機的関連の存在する可 能性を示唆するものとも考之られる。ともかく この問題は老化という極めて複雑な生体機能の 中で検討される必要があり，高令者における好 中球 $\mathrm{O}_{2}-$ 産生能低下の解明は今後のより多角的 な検討にまたざるを得ない。

以上本編においては上卜好中球 $\mathrm{O}_{2}^{-}$産生能に 関する基礎的研究を行なうなかで, in vitroか ら in vivo 状態での推定, さらに多数例の正常 七卜好中球 $\mathrm{O}_{2}-$ 産生能の検討加ら宿主要因, 特 に加令の $\mathrm{O}_{2}$-産生能に及ほす影響を明確にした。 細胞内殺菌能を示す生化学的示標のひとつと考 之られる $\mathrm{O}_{2}{ }^{-}$産生能の測定は，その方法が比較 的簡便でかつ再現性のあることから，今後各病 態の解明に際しその応用が期待されるものと思 われる. 又今回明らかにした高令者層における 好中球 $\mathrm{O}_{2}-$ 産生能低下は，本法の臨床応用とそ の成績の意義づけを検討する際 back ground として必要であると同時に，今後老化現象の病 態解析に際し極めて重要な情報を提供するもの であろう。

結語

急性白血病における易感性を好中球 $\mathrm{O}_{2}-$ 産生 能の面から解明することを目的とし，まず本編 
では正常ヒト好中球を对象とした実験条件の恰 討，並びに宿主因子としての性別，加令の影響 を検討した。その結果,

1. 好中球 $\mathrm{O}_{2}{ }^{-}$産生能測定における至適実験条 件は以下のごとくであった。

a：白血球保存温度は $0{ }^{\circ} \mathrm{C}$ で保存時間は60分 以内である。

b. 反応液中の白血球細胞濃度は0.2 0.5 $10^{6} \sqsupset / m \ell て ゙ あ る 。$

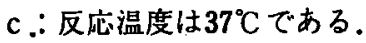

d. 反応液 $\mathrm{pH}$ は7.4である。

2. 正常七ト 3 名における好中球 $\mathrm{O}_{2}{ }^{-}$産生能測 定值の変動係数（CV）は平均10.9であった。

3. 20〜69才の45名についてその好中球 $\mathrm{O}_{2}^{-}$産 生能を性別において比較すると，男性6.45士 1.38 .女性6.43土1.25 nmol $/ \mathrm{min} / 10^{6} \mathrm{PMNs}$ であり，両者に有意差は認められなかった。

4. 20 89才の計67名の好中球 $\mathrm{O}_{2}^{-}$産生能を一 括して算出すると $5.88 \pm 1.56 \mathrm{nmol} / \mathrm{min} / 10^{6}$ PMNsであったが，これを20〜69才の非高令 者群と70〜89才の高令者群の 2 群で比較する
と，前者が6.45土1.33であるのに比し後者は $4.72 \pm 1.37 \mathrm{nmol} / \mathrm{min} / 10^{6} \mathrm{PMNs}$ と高令者群 において有意の低下が認められた。

以上の結果を得たので報告したが，正常ヒト 好中球 $\mathrm{O}_{2}-$ 産生能湘定はその簡易性, 再現性か らして, 今後各種病態の解明に際し有用な方法 とし臨床応用が期待されるものと思われる、又 高令者における好中球 $\mathrm{O}_{2}{ }^{-}$産生能の低下は好中 球の細胞内殺菌能低下を示唆するものであり, 高令者での易感染性とその難治化という特異性 を好中球機能の面から説明するものであると言 える.さらにまた，老化現象の検討に際し重要 な情報を提供するものと思われる。

稿を終えるにあたり御指導ならびに御校閲を賜っ た恩師木村郁郎教授に樑謝するとともに，終始琶切 なる御指導と助言をいただいた喜多嶋康一助教授並 びに高橋功講師に感謝の意を表する。

尚本論文の要旨は第41回日本血液学会桧会（1979 年東京)において発表した。

\section{文献}

1. 妹尾左知丸：白血球の食作用。代謝，14，961-967，1977.

2. Quie, P.G.: Pathology of bactericidal power of neutrophils. Semin. Hematol. 12, 143-160, 1975.

3 Klebanoff, S.J.: Antimicrobial mechanisms in neutrophilic polymorphonuclear leukocytes. Semin. Hematol. 12, 117-142, 1975.

4. Cheson, B.D., Curnutte, J.T., Babior, B.M.: The oxidative killing mechanisms of the neutrophil. Prog. Clin. Immunol. 3, 1-65, 1977.

5. Nakamura, M., Nakamura, M., Okamura, J., Kobayashi, Y.: A rapid and quantitative assay of phapocytosis-connected oxygen consumption by leukocytes in whole blood. J. Lab. Clin. Med. , 568$575,1978$.

6. Sbarra, A.J., Karnovsky, M.L.: The biochemical basis of phagocytosis. I. Metabolic changes during the ingestion of particles by polymorphonuclear leukocytes. J. Biol. Chem. 234, 1355-1362, 1959.

7. Weening, R.S., Roos, D., Loos, J.A.: Oxygen consumption of phagocytizing cells in human leukocyte and granulocyte preparations: a comparative study. J. Lab. Clin. Med. 83, 570-576, 1974 .

8. Reed, P.W:: Glutathion and hexose monophosphate shunt in phagocytizing and hydrogen peroxidetreated rat leukocyte. J. Biol. Chem. 244, 2459-2464, 1969.

9. Skeel, R.T., Yankee, R.A, Spivak, W.A., Novikovs, L., Henderson, E.S.: Leukocyte preservation. I. Phagocytic stimulation of the hexose monophosphate shunt as a measure of cell viability. J. Lab. Clin. Med. 73, 327-337, 1969. 
10. Babior, B.M., Kipnes, R.S., Curnutte, J.T.: Biological defense mechanisms. The production by leukocytes of superoxide, a potential bactericidal agent. L. Clin. Invest. 52, 741-744, 1973.

11. Root, R.K., Metcalf, J., Oshino, N., Chance, B.: $\mathrm{H}_{2} \mathrm{O}_{2}$ release from human granulocytes during phagocytosis. 1. Documentation, quantitation, and some regulating factors . J. Clin. Invest. 55, 945-955, 1975.

12. Weening, R.S. Wever, R., Roos, D.: Quantitative aspects of the production of superoxide radicals by phagocytizing human granulocytes. J. Lab. Clin. Med. 85, 245-252, 1975.

13. Tauber, A.I., Babior, B.M.: Evidence for hydroxyl radical production by human neutrophils. J. Clin. Invest. 60, 374-379, 1977.

14. Holmes, B., Page, A.R., Good, R.A.: Studies of the metabolic activity of leukocytes from patients with a genetic abnomality of phagocytic function. J. Clin. Invest. 46, 1422-1432, 1967.

15. Mandell, G.L., Hook, E.W.: Leukocyte function in chronic granulomatous disease of childhood. Studies on a 17-year-old boy. Am. Med. 47, 473-486, 1969.

16. Nakagawara, A., Kakinuma, K., Shin, H., Miyazaki, S., Minakami, S.: Lack of cytochalasin E-induced superoxide release by polymorphonuclear leukocytes of patients with chronic granulomatous disease A new diagnostic test. Clin. Chim. Acta. 70, 133-137, 1976.

17. Curnutte, J.T., Whitten, D.M., Babior, B.M.: Defective superoxide production by granulocytes from patients with chronic granulomatous disease. N. Engl. l. Med. 290, 593-597, 1974.

18. Baehner, R.L., Nathan, D.G.: Deficient glucose oxidation in the intact leukocytes of chronic granulomatous disease. Blood 28, 1010-1011, 1966.

19. Quie, P.G., White, J.G., Holmes, B., Good, R.A.: In vitro bactericidal capacity of human polymorphonuclear leukocytes. Diminished activity in chronic granulomatous disease in childhood. $\quad$. Clin. Invest. 46, 668-679, 1967.

20. Curnutte, J.T., Babior, B.M.: Biological defense mechanisms. The effect of bacteria and serum on superoxide production by granulocytes. J. Clin. Invest. 53, 1662-1672, 1974.

21. Iyer, G.Y.N., Islam, D.M.F., Quastel, J.H.: Biochemical aspects of phagocytosis. Nature 192, 535$541,1961$.

22. Allen, R.C., Stjernholm, R.L., Steele, R.H.: Evidence for the generation of an electronic excitation states in human polymorphonuclear leukocytes and its participation in bactericidal activity. Biochem. Biophys. Res. Commun. 47, 679-684, 1972.

23. Rosen, H., Klebanoff, S.J.: Chemiluminescence and superoxide production by myeloperoxidase-deficient leukocytes. J. Clin. Invest. 58, 50-60, 1976.

24. Nakagawara, A., Nabi, B.Z.F., Minakami, S.: Improved procedure for the diagnosis of chronic granulomatous disease, using concanavalin A and cytochalasin E. Clin. Chim. Acta 74, 173-176, 1977.

25. Takeshige, K., Matsumoto, T., Shibata, R., Minakami, S.: Simple and rapid method for the diagnosis of chronic granulomatous disease, measuring hydrogen peroxide and superoxide anions released from leukocytes in whole blood. Clin. Chim. Acta 92, 329-335, 1979.

26. Gale, R.T.: Advances in the treatment of acute myelogenous leukemia. N. Engl. J. Med. $3001189-$ $1199,1979$.

27. Levine, A.S., Deisseroth, A.B.: Recent developments in the supportive therapy of acute myelogenous leukemia. Cancer 42, 883-894, 1978.

28. Bodey, G.P., Rodriguez, V., Chang, H., Narboni, G.: Fever and infection in leukemic patients. Cancer $41,1610-1622,1978$. 
29. Klebanoff, S.J., Hamon, C.B.: Role of myeloperoxidase-mediated antimicrobial systems in intact leukocytes. J. Reticuloendothel. Soc. 12, 170-196, 1972.

30) Nakamura, M., Nakagawara, A., Minakami, S.: Mimicking of phagocytic metabolism of leucocytes suspended in heavy water $\left(\mathrm{D}_{2} \mathrm{O}\right)$. Exp. Cell Res. 102, 429-431, 1976.

31. DcChatelet, L.R., Shirley, P.S., Johnston, R.B.: Effect of phorbol myristate acetate on the oxidative metabolism of human polymorphonuclear leukocytes. Blood 47, 545-554, 1976.

32) Goldstein, I.M., Roos, D., Kaplan, H.B., Weissmann, G.: Complement and immunoglobulins stimulate superoxide production by human leukocytes independently of phagocytosis. J. Clin. Invest. 56, 1155$1163,1975$.

33. Simchowitz, L., Mehta, J., Spilberg, I.: Chemotactic factor-induced superoxide radical generation by human neutropnils. J. Lad. Clin. Med. 94, 403-413, 1979.

34) McCord, J.M., Fridovich, I.: Superoxide dismutase. An enzymic function for erythrocuprein (hemocuprein). l. Biol. Chem. 244, 6049-6055, 1969.

35. Johnston, R.B., Keele, B.B., Misra, HP., Lehmeyer,. J.E., Webb, L.S., Baehner, R.L., Rajagopalan, K.V. : The role of superoxide anion generation in phagocytic bactericidal activity. Studies with normmal and chronic granulomatous disease leukocytes. J. Clin. Invest. 55, 1357-1372, 1975.

36. Rosen, H., Klebanoff, S.J.: Bactericidal activity of a superoxide anion-generation system. A model for the polymorphonuclear leukocyte. J. Exp. Med. 149, 27-39, 1979.

37. Babior, B.M., Curnutte, J.T., Kipnes, R.S.: Biological defense defense mechnisms. . Evidence for the participation of superoxide in bacterial killing by xanthine oxidase. J. Lab. Clin. Med.. 85, 235 $-244,1975$.

38. Selvaraj, R.J., Zgliczynski, J.M., Paul, B.B., Sbarra, A.J.: Enhanced killing of myeloperoxidase-coated bacteria in the myeloperoxidase- $\mathrm{H}_{2} \mathrm{O}_{2}$-Cl-system. J. Infect. Dis. 137, 481-485, 1978.

39. Cohen, H.J., Chovaniec, M.E.: Superoxide generation by digitonin-stimulated guinea pig granulocytes. A basis for a continuous assay for monitoring superoxide production and for the study of the activation of the generating system. J. Clin. Invest. 61, 1081-1087, 1978.

40. Gabig, T.G., Bearman, S.I., Babior, B.M.: Effects of oxygen tension and $\mathrm{pH}$ on the respiratory hurst of human neutrophils. Blood 53, 1139, 1979.

41. Hays, R.C., Mandell, G.L.: $\mathrm{pO}_{2}, \mathrm{pH}$, and redox poxential of experimental abscesses. Proc. Soc. Exp. Biol. Med. 147, 29-30, 1974.

42. 松本慶蔵: 老人の感染症, 最新医学, 31, 1258-1264, 1976 .

43. Moroni, M., Capsoni, F., Caredda,F., Lazzarin, A., Besana, C.: Dimostrazione di un difetto granulocitario in soggetti anziani e correlazione con la presenza di auto-anticorpi. Boll. 1st Sieroter Milan. 55, 317-322, 1916.

44. Silverman, E.M., Silverman, A.G.: Granulocyte adherence in the elderly. Am. J. Clin. Pathol. 67, 49-52, 1977.

45. Auclair, C., Torres, M., Hakim, J., Troube, H.: NADPH-oxidation activities in subcellular fractions isolated from resting on phagocytizing human polymorphonuclears. Am. J. Hematol. 4, 113-120, 1978.

46. Dewald, B., Baggiolini, M., Curnutte, J.T., Babior, B.M.: Subcellular localization of the superoxideforming enzyme in human neutrophils. J. Clin. Invest. 63, 21-29, 1979.

47. Briggs, R.T., Drath, D.B., Karnovsky, M.L., Karnovsky, M.J.: Localization of NADH oxidase on the surface of human polymorphonuclear leukocytes by a new cytochemical method. J. Cell. Biol. 67 , 
$566-586,1975$.

48. Stossel, T.P.: Phagocytosis: Recognition and ingestion. Semin. Hematol. 12, 83-116, 1975.

49. Goldstein, I.M., Weissmann, G.: Nonphagocytic stimulation of human polymorphonuclear leukocytes: Role of the plasma membrane. Semin. Hematol. 16, 175-187, 1979.

50. 平井圭一, 上野聰樹, 小川和朗 : 肺胞食細胞膜の $\mathrm{NAD}(\mathrm{P}) \mathrm{H}$ oxidase と superoxide dismutase. 最新医学. $35,718-723,1980$.

51. Rossi,,F., Zatti, M., Patriaraca, P., Cramer, R.: Effect of specific antibodies on the metabolism of quinea pig polymorphonuclear leukocytes. J. Reticuloendotel. Soc. 9, 67-85, 1971.

52. Briggs, R.T., Karnovsky, M.L, Karnovsky, M.J.: Hydrogen peroxide production in chronic granulomatous disease. A cytochemical study of reduced pyridine nucleotide oxidases. J. Clin. Invest. 59, 1088-1098, 1977.

53. Weissmann, G., Smolen, J.E., Korchak, H.M.: Release of inflammatory mediators from stimulated neutrophils. N. Engl. J. Med. 303, 27-34, 1980.

54. 佐野 清：糖尿病における白血球の機能に関する研究．第 1 編 好中球スーパーオキサイト産生能。岡山 医学会雑誌. 91，713-722, 1979.

55. Curnutte, J.T., Babior, B.M.: Effects of anaerobiosis and inhibitors on $\mathrm{O}_{2}{ }^{-}$production by human granulocytes. Blood 45, 851-861, 1975.

56. Cohen, H.J., Chovaniec, M.E.: Superoxide production by digitonin-stimulated gunea pig granulocytes. The effects of $\mathrm{N}$-etyl maleimide, divalent cations, and glycolytic and mitochondrial inhibitors on the activation of the superoxide generating system. J. Clin. Invest. 61, 1088-1096, 1978.

57. Cooper, M.R., DeChatelet, L.R., McCall, C.E., LaVia, M.F., Spurr, C.L., Baehner, R.L.: Complete defiency of leukocyte glucose-6-phosphate dehydrogenase with defective bactericidal activity. J. Clin. Invest. 51, 769-778, 1972.

58. 平井俊策：老化と活性酸素. 代謝. $15,55-61,1978$.

59. 松尾光芳：老化と遊離基. 医学のあゆみ. 97，581-587， 1976.

60. 饭田久也, 今井篤志, 野沢義則, 木村德次：脂質過酸化に上る膜機能の変化。過酸化脂質研究。 $3,54-$ $57,1979$.

61. 藤田 直，安田正秀：過酸化脂質と生体膜。日薬理誌。72，279-286，1976。

62. 小川和朗, 田中輝男：膜破壊と機能原子因の電子顕微鏡的細胞化学. 最新医学. 33，670-676, 1978.

63. Cooper, R.A.: Abnomalities of cell-membrane fluidity in the pathogenesis of disease. N. Engl. J. Med. 297, 371-377, 1977.

64. Tappel, A.L.: Lipid peroxidation damage to cell components. Fed. Proc. 32, 1970-1874. 1973.

65. Holliday, R., Tarrant, G.M.: Altered enzymes in aging human fibloblasts. Nature. 238, 26-30,1972. 


\title{
Studies on superoxide production of human neutrophils
}

Part 1. Experimental studies on superoxide production of human neutrophils

\author{
Fumikazu KOHI \\ Department of Internal Medicine, Okayama University \\ Medical School Okayama 700, Japan
}

(Director: Prof. I. Kimura)

\begin{abstract}
Patients with acute leukemia are prone to get infections. Pathological conditions such as leukocytopenia and disturbances of humoral and cellular immunity are thought to contribute to this high susceptibility to infection.

Superoxide, one of the active oxygens, is thought to be related to the intracellular bactericidal activities of neutrophils, particularly in oxygen dependent systems. These findings led the author to speculate that primary and secondary disturbances in the superoxide production of neutrophils are of importance in the high susceptibility of patients with acute leukemia. In this experiment, the superoxide production of normal human neutrophils stimulated by Concanavalin A and Cytocharacin D was assayed by spectrophotometer in order to evaluate its usefulness in clinical applications. The ef fect of age and sex on supreoxide production was also examined. The following results were obtained:

1. The activity of superoxide production was affected by both time and temperature during cell preservation. It was also dependent on the cell concentration, temperature and $\mathrm{pH}$ during stimulation of the neutrophils. The optimal system for assay of the superoxide production of human neutrophils was as follow: Cells should be preserved at $0^{\circ} \mathrm{C}$ within 60 minutes. During stimulation, cell concentration, temperature and $\mathrm{pH}$ should be ajusted to $0.2-0.5 \times 10^{6} / \mathrm{ml}, 37^{\circ} \mathrm{C}$ and 7.4 , respectively.

2. There were no significant changes in superoxide production between males and females. Superoxide production in older subjects(70-89 y/o) was significantly lower than that in younger subjects $(20-69 \mathrm{y} / \mathrm{o})(\mathrm{p}<0.001)$. The values were $4.72 \pm 1.17 \mathrm{nmol} / \mathrm{min} / 106$. PMNs in the former and $6.45 \pm 1.33 \mathrm{nmol} / \mathrm{min} / 10^{6} \mathrm{PMNs}$ in the latter.

Assays of superoxide production of human neutrophils can be clinically used because of its simplicity and reproducibility. It was apparent that the assessment of superoxide production of neutrophils by age was necessary in clinical applications.
\end{abstract}

